\title{
Geomorphological Feature - A Narrow Rock Bridge, Umthongkut Area, West Khasi Hills District, Meghalaya
}

Meghalaya is known for its scenic beauty. Natural rock arch/bridges are reported throughout the world and a few of them became popular. One such 'Rock Bridge', is present at Umthongkut village in West Khasi Hills district, Meghalaya, lies approximately $204 \mathrm{~km}$ southwest of Shillong (Fig 1). The site is well connected by metal road of $180 \mathrm{~km}$ from Shillong to Maheskhola via Gomaghat, however,

further stretch of $24 \mathrm{~km}$ is a foot walk on a very tough and rugged terrain. The area forms a part of Toposheet No. 78K/15, bound by Latitude: $25^{\circ} 17,18.5^{\prime \prime} \mathrm{N}$ and longitude: $90^{\circ} 55^{\prime} 57.6^{\prime \prime} \mathrm{E}$, situated in dense forest, along the fringes of Balphakaram National Park and infested with wildlife.

The rock bridge is $17 \mathrm{~m}$ long, width ranging from $0.56 \mathrm{~m}$ to $1.45 \mathrm{~m}$ and appears to be 'one of the narrowest' of all the worlds

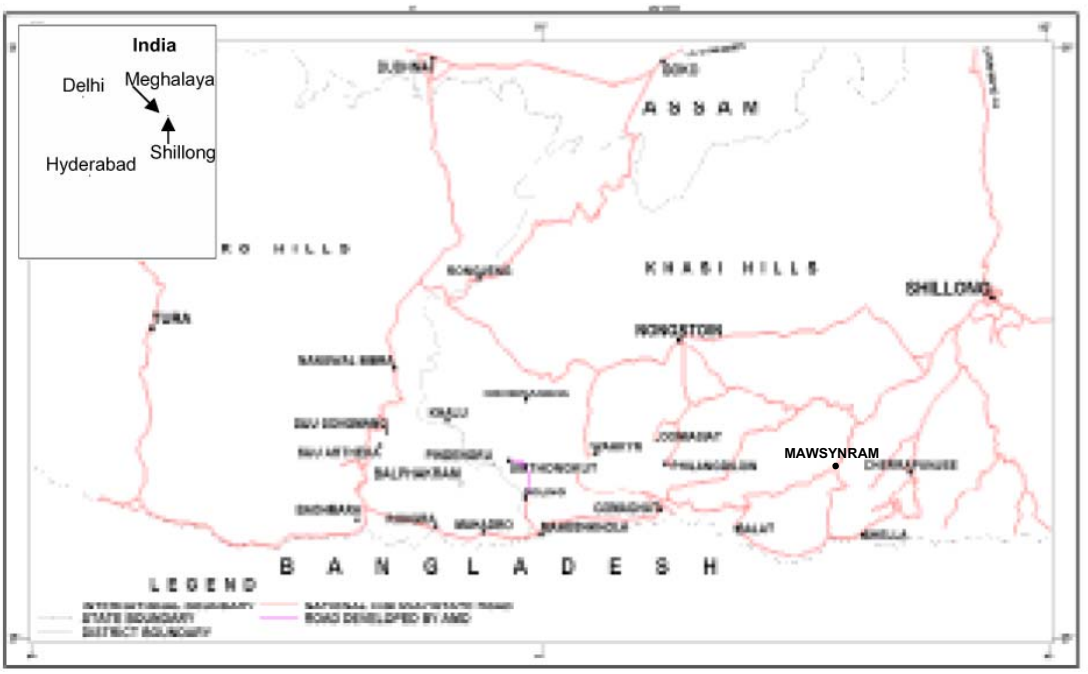

Fig.1. Location map of natural rock bridge, Umthongkut area, Meghalaya.

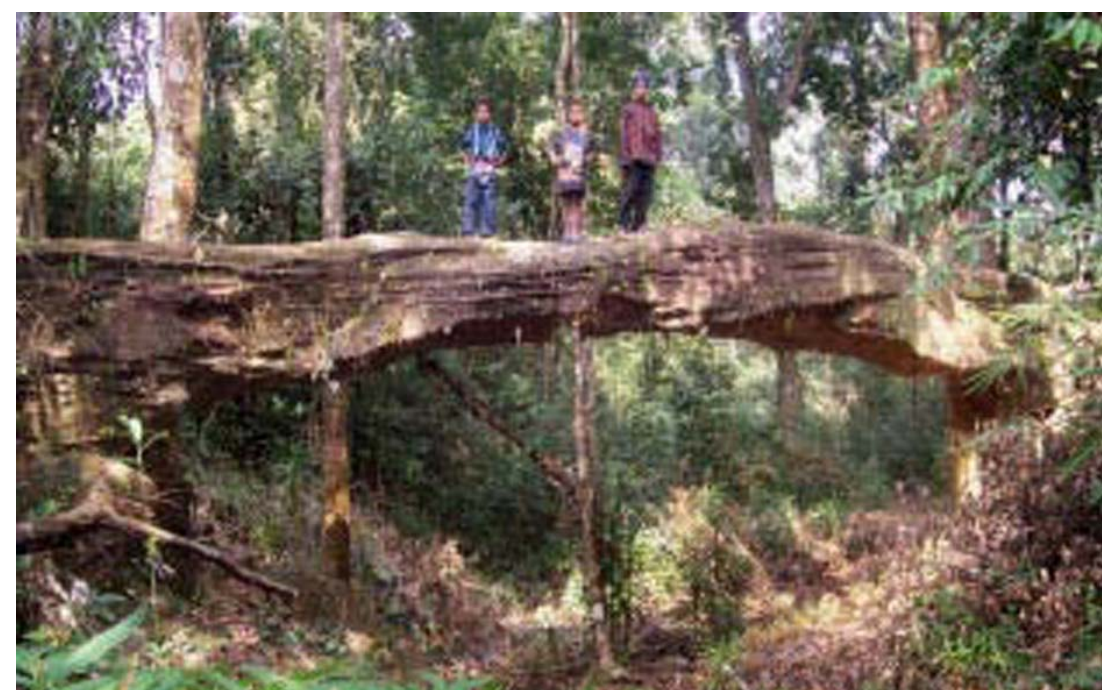

Fig.2. Photograph of natural rock bridge. reported natural rock bridges. Its thickness is as low as $0.35 \mathrm{~m}$ at certain point with a maximum of $1.15 \mathrm{~m}$, found hanging $4.4 \mathrm{~m}$ above the center of the nala (Fig. 2) and characterized by differential weathering.

Geologically, the area comprises sandstone, shale with coal seams and fossiliferous limestone belonging to Tura and Siju Formation of Tertiary age. The rock bridge is exclusively made up of fine- to medium-grained sandstone that display variegated shades of grey, brown and buff colour. Under the microscope, rocks are texturally immature and ill sorted, composed predominantly of subangular to subrounded framework clasts of quartz, set in a clayey matrix and bound by ferruginous cementing material. The bridge appear to be formed by the collapse of an underground drainage leaving the relic of tunnel ceiling and the present shape is attained due to macroscopic and microscopic erosion occurred by dissolving the crystalline cement and dispersing the loose grains.

Rock bridge at Umthongkut village is an unusual geomorphological feature. Such features, attract not only the geoscientist but also given importance of tourism. Therefore, it becomes imperative to preserve such incredible monument and needs its proper placement in the tourism map of Meghalaya.

Acknowledgements: Authors are indebted to Regional Director Dr. R. Mohanty for his long standing support during our field programmes. We also express our gratitude to Additional Director Shri P. S. Parihar and Director, Dr. Anjan Chaki for giving permission to publish this article.

\begin{tabular}{|c|c|}
\hline Department of & S.K. SRivastava*, \\
\hline Atomic Energy, & P.K. KOTHARI, \\
\hline Shillong & $\begin{array}{l}\text { SANDEEP HAMILTON } \\
\text { and AMIT MAJUMDAR }\end{array}$ \\
\hline
\end{tabular}

